DOI https://doi.org/10.32782/2305-9389/2020.23.20

УДК 336.14:321

\author{
Гнатенко Валерій,
}

orcid.org/0000-0003-2659-9202

кандидат економічних наук, науковий співробітник

Д3 «Науково-практичний медичний реабілітаційно-діагностичний иенттр

Міністерства охорони здоров'я Украӥни»

\title{
ДЕРЖАВНЕ РЕГУЛЮВАННЯ БЮДЖЕТНОГО ПРОЦЕСУ В СИСТЕМІ ЕКОНОМІЧНОГО ПРОЦЕСУ
}

\begin{abstract}
Бюджетна політика є одним із вагомих інструментів державного регулювання економіки. Від ефективності бюджетного прочесу, формування бюджетної політики залежить успішність реалізації регулюючої функиї держави, забезпечення економічного зростання.

У статті розглянуті та проаналізовані чинне законодавство та теоретичні підходи щзоо тлумачення бюджетного прочесу, його регулювання. Наголочено на законодавчому закріпленні терміна «бюджетний прочес» $і$ проаналізовано позиції науковців стосовно його змісту та характерних рис та стадій. Усі стадії бюджетного проиесу регламентовані процесуальними нормами бюджетного права та засновуються на правових засадах, які мають гарантувати чітке планування, дотримання бюджетної дисиипліни і постійний контроль за виконанням усіх видів бюджетів.

Виокремлено проблеми бюджетного процесу в Україні, щзо полягають у несвоєчасності його прийнятті, відсутності стратегії щзодо планування бюджету, контролю і відповідальності за виконанням бюджету. Зазначено, щуо проблемні аспекти організаџії бюджетного процесу в Украӥні вимагають негайного вирімення на кожній його стадії, що в перспективі дасть змогу забезпечити ефективне управління державними фінансовими ресурсами, підвищити результативність, ефективність і прозорість використання бюджетних коштів, уникнути зриву бюджетного прочесу через політичні подї, підвищити якість головного фінансового документа держави та стане міцним підтрунтям для забезпечення соціально-економічного розвитку Украӥни.
\end{abstract}

Ключові слова: національна безпека, бюджетний процес, проблеми бюджетного процесу, реформування бюджетного процесу.

\section{Hnatenko Valeriy. State regulation of the budget process in the system of economic process}

Fiscal policy is one of the important tools of state regulation of the economy, due to the effectiveness of the budget process and the formation of fiscal policy the success of the regulatory function of the state and ensuring of economic growth depend on.

The current legislation and theoretical approaches to the interpretation of the budget process, its regulation has been considered and analyzed in this article. It has been emphasized the legislative enshrinement of the term "budget process" and the positions of scientists regarding its content and characteristics and stages have been analyzed. All stages of the budget process are regulated by procedural norms of the budget law and are based on legal principles, which should guarantee clear planning, observance of budgetary discipline and constant control over the execution of all types of budgets.

The problems of the budget process in Ukraine are highlighted, which are in the late adoption, lack of strategy for budget planning, control and responsibility for budget execution. It has been noted that the problematic aspects of the budget process organization in Ukraine require immediate solution at each stage, which in the future will ensure effective management of public financial resources, increase efficiency, effectiveness and transparency of budget funds, avoid disruption of the budget process due to political events, improve the quality of the main financial document of the state and will be a solid foundation for ensuring the socio-economic development of Ukraine.

Key words: national security, budget process, problems of budget process, reformation of budget process.

Постановка проблеми. Упродовж останніх років однією з цілей реформ, що здійснюються в національній економіці, $є$ підвищення ефективності та прозорості бюджетної складової частини. Сучасні виклики фінансово-економічного розвитку зумовлюють необхідність удосконалення та розвитку в управлінні бюджетним процесом. Однією з головних умов ефективного регулювання економічних процесів у державі є прозорість та зрозумілість державної політики.

3 огляду на це можна констатувати труднощі в процесі встановлення сутності і змісту цього економічного поняття.

Аналіз останніх досліджень і публікацій. Взагалі термін «бюджетний процес» вивчався в науковій літературі ще у 60-70 pp. минулого століття такими вченими фінансистами, як Є.А. Ровинський, М.I. Пискотін, Н.І. Хімічева. У 1975 р. професор Л.К. Воронова бюджетний процес визначила «як регламентовану правовими нормами діяльність державних органів зі складання, розгляду, затвердження звіту та його виконання» [4]. 
Надалі це питання розглядали вітчизняні та закордонні науковці, учені-економісти, експерти в бюджетній сфері, а саме: Л.В. Фещенко, П.В. Проноза, Н.В. Кузьминчук [10], В.Г. Дем’янишин [5], К.В. Павлюк [7], I.С. Януль [13], Н.І. Хімічева [11], а також незалежні експерти Міжнародного бюджетного партнерства. Вагомий внесок у розгляд питання формування та реалізації бюджетної політики в умовах економічних перетворень, iї впливу на соціально-економічний розвиток суспільства зробили такі вітчизняні вчені, як І.Я. Чугунов, К.В. Брижан [12], Т.В. Бугай [1].

Водночас залишається потреба в додатковому комплексному аналізі бюджетного процесу в Україні 3 метою виявлення недоліків та підготовки рекомендацій щодо їх усунення.

Мета статті - проаналізувати переваги, передумови та обгрунтувати необхідність регулювання бюджетного процесу в Україні з позиції національної безпеки.

Виклад основного матеріалу. Бюджетна політика $є$ одним із вагомих інструментів державного регулювання економіки, від ефективності бюджетного процесу, формування бюджетної політики залежить успішність реалізації регулюючої функції держави, забезпечення економічного зростання. Метою бюджетної політики $є$ забезпечення відповідного рівня соціально-економічного розвитку суспільства з урахуванням збалансованості державних фінансів, що реалізується через інститути бюджетного регулювання. Бюджетна політика має бути спрямована на проведення економічних перетворень, створення відповідних умов для підвищення їі ефективності та конкурентоспроможності, довгострокового економічного розвитку, покращення інвестиційного середовища [12].

Бюджетний процес - поняття, яке містить у собі сукупність етапів від складання проєкту бюджету, розгляду, затвердження, виконання до моменту складання звіту щодо його виконання та затвердження, що належать до бюджетної системи України, та має нерозривний зв'язок із фінансами, економікою, політикою, правом, соціологією тощо.

У законодавстві та фаховій літературі можна знайти таке трактування сутності «бюджетного процесу»:

\begin{tabular}{|c|c|}
\hline Автор/джерело/рік & Визначення \\
\hline $\begin{array}{l}\text { Бюджетний кодекс України } \\
\text { (Документ 2456-VI, } \\
\text { Редакція від 01.01.2021р.) [3] }\end{array}$ & $\begin{array}{l}\text { Бюджетний процес - регламентований бюджетним законодавством } \\
\text { процес складання, розгляду, затвердження, виконання бюджетів, } \\
\text { звітування про їх виконання, а також контролю за дотриманням } \\
\text { бюджетного законодавства. }\end{array}$ \\
\hline $\begin{array}{l}\text { Л.В. Фещенко, П.В. Проноза, } \\
\text { Н.В. Кузьминчук } \\
\text { Бюджетна система України: } \\
\text { навчальний посібник (2008) [10] }\end{array}$ & $\begin{array}{l}\text { Бюджетний процес являє собою регламентовану нормами права } \\
\text { діяльність, яка пов’язана зі складанням, розглядом, затверджен- } \\
\text { ням, виконанням бюджетів, контролем за їх виконанням, розглядом } \\
\text { та затвердженням звітів про виконання бюджетів, що входять до } \\
\text { складу бюджетної системи України. }\end{array}$ \\
\hline В. Дем'янишин (2007) [5] & $\begin{array}{l}\text { Бюджетний процес - це діяльність органів державної влади, дер- } \\
\text { жавного управління, місцевого самоврядування та усіх учасників } \\
\text { бюджетних відносин, що здійснюється на основі відповідних прин- } \\
\text { ципів, положень, заходів, методів та засобів, регулюється право- } \\
\text { вими нормами і пов’язана зі складанням, розглядом, затверджен- } \\
\text { ням, виконанням, розглядом і затвердженням звітів про виконання } \\
\text { бюджету держави й усіх його ланок. }\end{array}$ \\
\hline К. Павлюк (2006) [7] & $\begin{array}{l}\text { Бюджетний процес - це діяльність законодавчих, виконавчих і } \\
\text { судових органів влади, пов’язана з формуванням цілей і завдань } \\
\text { бюджетної політики на наступний бюджетний рік і середньостро- } \\
\text { кову перспективу, зі складанням, розглядом і затвердженням бюдже- } \\
\text { тів, оцінкою отриманих результатів і контролем на всіх цих етапах, } \\
\text { організацією управління такою діяльністю. }\end{array}$ \\
\hline I. Януль (2005) [13] & $\begin{array}{l}\text { Бюджетний процес не обмежується лише підготовкою закону } \\
\text { про асигнування коштів за групами статей видатків бюджету - це } \\
\text { постійний процес визначення пріоритетів держави, їі завдань та } \\
\text { функцій на певному етапі, розроблення відповідних цільових про- } \\
\text { грам, формування управлінських стратегій, оцінки ефективності } \\
\text { бюджетних коштів, контролю за дотриманням бюджетного законо- } \\
\text { давства та виконанням бюджетних повноважень. }\end{array}$ \\
\hline Н. Хімічева (2004) [11] & $\begin{array}{l}\text { Бюджетний процес - це регламентована нормами процесуального } \\
\text { бюджетного права діяльність держави та муніципальних утворень } \\
\text { щодо складання, розгляду і затвердження бюджету, його виконання, } \\
\text { а також складання і затвердження звіту про його виконання. }\end{array}$ \\
\hline
\end{tabular}


До учасників бюджетного процесу належать:

1) Верховна Рада України, яка затверджує Основні напрями бюджетної політики, на основі чого складається проєкт бюджету, розглядає проєкт бюджету та проєкт закону про державний бюджет, затверджує його. На стадії вона виконання бюджету контролює та вносить зміни, доповнення до Закону про Державний бюджет. На заключній стадії розглядає звіт щодо виконання державного бюджету та в разі згоди затверджує його. Верховній Раді України протягом всіх стадій бюджетного процесу допомагають всі їі комітети, насамперед профільні, - Комітет із питань бюджету та Комітет із питань фінансової та банківської діяльності;

2) Рахункова палата, до основних функцій якої належать:

- контроль за виконанням законів України та постанов із фінансових питань, що були прийняті ВРУ, за фінансуванням загальнодержавних програм, виконанням державного бюджету України;

- контроль за своєчасним та повним надходженням доходів до державного бюджету, за квартальним розподілом доходів і видатків відповідно до показників, а також за видатками щодо обслуговування внутрішнього та зовнішнього боргу України;

- перевірка в межах компетенції кошторисів видатків, які пов'язані з діяльністю ВРУ, апарата ПУ та КМУ;

- контроль за витрачанням коштів державними бюджетними установами та організаціями, які здійснюють свою діяльність за межами України;

- контроль за використанням коштів державного бюджету та місцевих бюджетів у частині фінансування повноважень місцевих державних адміністрацій та делегованих місцевому самоврядуванню повноважень органів виконавчої влади щодо доходів та видатків (ст. 98 Конституції України, Висновки Конституційного Суду України від 21 грудня 2000 р., № 4-в/2000);

3) Президент України як голова держави, відповідно до ст.ст. 96, 106 Конституції України, визначає основні напрями внутрішньої та зовнішньої політики, на яких грунтується бюджетна політика загалом;

4) Кабінет Міністрів України, центральні і місцеві виконавчі органи, які беруть участь у складанні проєктів бюджетів і юридичних актів про бюджет та їх виконання;

5) Міністерство фінансів України;

6) Державне казначейство України;

7) Державна контрольно-ревізійна служба України;

8) Державна податкова служба України;

9) органи місцевого самоврядування та державні адміністрації є суб'єктами бюджетних правовідносин у межах повноважень згідно з Конституцією України, законами України «Про місцеве самоврядування», «Про місцеві державні адміністрації» та Бюджетним Кодексом України [9].

Усі стадії бюджетного процесу ретельно регламентовані процесуальними нормами бюджетного права, що забезпечує чітке планування та додержання бюджетної дисципліни. При цьому зазначені стадії слідують чітко послідовно, одна за одною та їх порядок не може бути змінений у жодному разі.

У бюджетному процесі також використовується програмно-цільовий метод, що застосовується на рівні державного бюджету та місцевих бюджетів, де учасниками бюджетного процесу виступають органи, установи, посадові особи, наділені бюджетними повноваженнями. Програмно-цільовий метод формування бюджету впроваджується в Україні з 2002 р. Використання цього методу бюджетного планування дає змогу оцінювати результативність державних програм та чітко визначити, на що саме витрачаються бюджетні кошти. Програмно-цільовий метод складання бюджету набув подальшого розвитку з прийняттям у липні 2010 р. нової редакції Бюджетної кодексу України, яким передбачено розширення сфери застосування програмно-цільового методу в бюджетному процесі.

Новий бюджетний кодекс України дає таке визначення програмно-цільового методу: програмноцільовий метод у бюджетному процесі - метод управління бюджетними коштами для досягнення конкретних результатів за кошти бюджету із застосуванням оцінки ефективності використання бюджетних коштів на всіх стадіях бюджетного процесу [2].

Сутність програмно-цільового методу складання бюджету полягає в тому, що процес формування бюджету починається із зосередження уваги спершу на результатах, яких необхідно досягти, а вже потім на ресурсах, потрібних для досягнення цих результатів [2].

Під час планування дохідної частини місцевого бюджету на 2020 рік та прогнозу на 2021-2022 роки в частині податкових і неподаткових надходжень та інших доходів доцільно керуватися:

1) основними прогнозними макропоказниками економічного і соціального розвитку України у 2020-2022 роках, затвердженими Постановою Кабінету Міністрів України від 15.05.2019 року № 555:

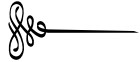


- ВВП у 2019 році очікується (млрд грн) - 4035,2; прогноз, відповідно, на 2020 рік - 4551,7; 2021 рік - 5069,9; 2022 рік - 5617,3 млрд грн, відповідно у відсотках до попереднього року - 102,8\%; $103,3 \% ; 103,8 \% ; 104,1 \%$;

- Індекс споживчих цін (грудень до грудня попереднього року, відсотки) у 2019 році очікується 107,4; прогноз: 2020 рік - 106,0 ; 2021 рік - 105,7; 2022 рік - 105,3;

- Індекс цін виробників (грудень до грудня попереднього року, у відсотках) у 2019 році очікується 111,1; прогноз: 2020 рік - 108,4; 2021 рік - 108,0; 2022 рік - 106,19 [10, с. 1-6].

2) основними прогнозними макропоказниками економічного і соціального розвитку України у 2021-2023 роках, затвердженими Постановою Кабінету Міністрів України від 29.07.2019 року № 671;

3) нормами Бюджетного та Податкового кодексів України $[9 ; 2 ; 8]$.

Контроль за виконанням бюджету в Україні здійснюється Рахунковою палатою, яка не має права накладати фінансові санкції, адміністративні стягнення до порушників бюджетного законодавства, а отже, в цьому випадку функція контролю не має результативного впливового значення. Діяльність Рахункової палати обмежується обов’язком інформувати органи влади з питань дотримання бюджетного законодавства та витрачання бюджетних коштів [1].

Варто зазначити, що основними векторами, здатними забезпечити ефективну реалізацію бюджетного процесу в Україні, є:

- забезпечення детальної та однозначної законодавчої регламентації всіх аспектів бюджетних правовідносин на кожній зі стадій бюджетного процесу;

- забезпечення визначення остаточного переліку прав, обов’язків і відповідальності органів і посадових осіб, що наділені бюджетними повноваженнями;

- посилення впливу інститутів громадянського суспільства на формування та реалізацію бюджетної політики держави;

- с створення механізму забезпечення відкритості та прозорості діяльності органів державної влади та органів місцевого самоврядування на кожній зі стадій бюджетного процесу;

- забезпечення якісної та ефективної професійної підготовки персоналу, зокрема підбору кадрів, які повинні мати не лише фахову спеціальність, а й галузевий фах відповідно до специфіки роботи;

- дотримання принципу системності та наукового супроводу під час здійснення заходів щодо реформування бюджетного процесу.

Постійною проблемою бюджетного процесу в Україні є його прийняття, оскільки відбувається хронічна несвоєчасність дій органів державної влади. Політична нестабільність та відсутність політичного консенсусу, відстоювання власних інтересів представниками влади зумовлюють надзвичайну проблематичність прийняття бюджету в строк.

Інша проблема бюджетного процесу полягає у відсутності стратегії щодо планування бюджету. Стратегічний розвиток держави та їі складників потребує довгострокових фінансових планів країни, а бюджет планується тільки на рік. У результаті цього фінансова бюджетна та соціальна економічні стратегії розвиваються паралельними шляхами замість того, щоб йти в одному напрямі і не створювати ще більших проблем державі [6].

Ключовою проблемою організації та реалізації бюджетного процесу в Україні є контроль і відповідальність за виконанням бюджету. Зокрема, проблема відповідальності криється в розумінні того, що нині фінансується з бюджету зазвичай не результат, а сама функція. Отже, у процесі розподілу фінансових ресурсів розпорядники бюджетних коштів мають їх «освоїти» у відведені терміни, а не ефективно інвестувати.

Щоб уникнути проблем у бюджетному процесі, варто доповнити Бюджетний Кодекс України нормами, що передбачали б відповідальність учасників бюджетного процесу за невиконання чи несвоєчасне виконання процедур формування і погодження проєкту закону «Про державний бюджет», а також проводити за допомогою незалежних експертів перевірку на кожній зі стадій бюджетного процесу.

Висновки. Реалізація механізму бюджетного регулювання інноваційного розвитку має спиратися на посилення взаємозв' язку бюджетного регулювання із циклічністю економічного розвитку, підвищення рівня обгрунтованості бюджетного планування, збалансування доходів і видатків бюджету, зниження частки державного боргу у валовому внутрішньому продукті, посилення контролю за використанням державних запозичень.

Проблемні аспекти організації бюджетного процесу в Україні вимагають негайного вирішення на кожній його стадії, що в перспективі дасть змогу забезпечити ефективне управління державними фінансовими ресурсами, підвищити результативність, ефективність і прозорість використання бюджетних коштів, уникнути зриву бюджетного процесу через політичні події, підвищити якість головного фінансового документа держави та стане міцним підгрунтям для забезпечення соціально-економічного розвитку України.

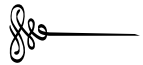




\section{Лiтература:}

1. Бугай Т.В. Сучасні проблеми та вектори розвитку бюджетного процесу в Україні. Збірник наукових праць Національного університету державної податкової служби України. 2012. № 2. С. 40-49.

2. Бюджетний кодекс України від 08 липня 2010 р. № 2456-VI (із змінами і доповненнями на 01.07.2019): URL: http://zakon3.rada.gov.ua/laws/show/2456-17 (дата звернення 01.02.2021 року).

3. Бюджетний кодекс України : Закон України № 2456-VI від 08.07.2010 р., редакція від 01.01.2021 р. Відомості Верховної Ради України (ВВР). 2010. № 50-51. Ст. 572. URL: https://zakon.rada.gov.ua/laws/show/2456-17\#Tеxt (дата звернення 02.02.2021 року)

4. Воронова Л.К. Бюджетно-правове регулювання в СРСР : монография. Київ : Вища школа, 1975. 320 с.

5. Дем’янишин В.Г. Концептуальні засади бюджетного процесу в Україні. Финансы, учет, банки. 2007. № 13. С. $30-37$.

6. Любич Н.П. Сутність та проблеми бюджетного процесу. Науковий вісник Національного університету біоресурсів $i$ природокористування Украӥни. 2013. Вип. 182. Ч. 1. С. 273-278.

7. Павлюк К.В. Бюджет і бюджетний процес в умовах транзитивної економіки України : монографія. Київ : НДФІ, $2006.584 \mathrm{c}$.

8. Податковий кодекс України від 02.10.2010 p. № 2736 - IV із змінами та доповненнями. URL: https://zakon.rada.gov.ua/ laws/show/671-2020-\%D0\%BF\#Text (дата звернення 07.02.2021 року)

9. Про схвалення Концепції застосування програмно-цільового методу в бюджетному процесі : Розпорядження Кабінету Міністрів України № 538-р від 14.09.2002 p. URL: http://zakon.rada.gov.ua/cgibin/laws/main. cgi?nreg=538-2002-\%F0 (дата звернення 01.02.2021 року)

10. Фещенко Л.В., Проноза П.В., Кузьминчук Н.В. Б 37 Бюджетна система України : навчальний посібник. Київ : Кондор, 2008. $440 \mathrm{c}$.

11. Финансовое право : учебник / отв. ред. Н.И. Химичева. [3-е изд., перераб. и доп.]. Москва : Юристъ, 2004. 749 с.

12. Чугунов І.Я., Брижан К.В. Бюджетна політика в умовах трансформації економіки. Економічний вісник універсиmету. 2017. Вип. 32(1). С. 241-251. URL: http://nbuv.gov.ua/UJRN/ecvu_2017_32\%281\%29_34 (дата звернення 07.02.2021 року)

13. Януль І.С. Бюджетний процес в Україні та напрями його вдосконалення. Фінанси Украӥни. 2005. № 9. С. 25-29. 